\title{
Penyuluhan kesehatan tentang menarche menggunakan metode ceramah pada siswi kelas VI
}

\author{
Eka Trismiyana ${ }^{\text {** }}$, Italia², Irma Rani Zofitri ${ }^{3}$
}

1Diploma III Keperawatan Universitas Malahayati Bandar Lampung. *Email: ekatrismiyana@gmail.com ${ }^{2}$ Stikes Mitra Adiguna Palembang. Email: italia.effendi@gmail.com

${ }^{3}$ Rumah Sakit Handayani Kotabumi Lampung Utara. Email: irmaranizofitri@yahoo.com

\section{Abstract \\ Knowledge regarding menstruation among elementary school girls}

Background: The adolescent stage is indicated by puberty signs and continued with sexual maturity. Puberty is a drastic change on the physical maturity including body and hormone changes signed by breast development, widen and enlarge hips, the growth of hair on armpits and vaginal area, and the sexual maturity signed by the first menstruation or menarche.

Purpose: To identify the effect of health counseling toward on knowledge regarding menstruation among elementary school girls

Method: A quantitative research by design quasi experiment with One Group Pretest-Posttest. The population was of 36 students girls in Grade V at Rejosari Elementary Public School 02 of Kotabumi of Lampung Utara Regency in 2019. It was taken by total technique, analyzed statistical by $T$ test dependent.

Results: The statistical test was conducted with T Test resulting $p$ - value 0.044 where $p$ value $<0.05$ that indicated there was an effect of health counseling toward on knowledge regarding menstruation among elementary school girls

Conclusion: This program to be continue in to other elementary school through community service join with public health centre local. Promoting and providing by distributing leaflet, poster or banner informing about menarche.

\section{Keywords: Knowledge; Menstruation; Elementary school girls}

Pendahuluan: Masa remaja ditandai sebagai masa dimana seseorang menunjukkan tanda-tanda pubertas dan berlanjut hingga dicapainya kematangan seksual. Pubertas adalah perubahan yang cepat pada kematangan fisik yang meliputi perubahan tubuh dan hormonalditandai oleh pertumbuhan payudara, pinggul melebar dan membesar, tumbuhnya rambut-rambut halus didaerah ketiak dan kemaluan serta dimulainya kematangan seksual yang ditandai dengan menstruasi pertama atau menarche.

Tujuan: Diketahui pengaruh penyuluhan kesehatan terhadap pengetahuan tentang menarche pada siswi kelas VI SDN.02 Rejosari Kota Bumi Kab. Lampung Utara Tahun 2019.

Metode: Jenis penelitian yang digunakan dalam penelitian ini adalah kuantitatif. Dalam penelitian ini menggunakan desain penelitian metode Quasi Eksperimental dengan pendekatan One group Pretes-Postes. Populasi dalam penelitian ini adalah seluruh siswi kelas V SDN.02 Rejosari Kota Bumi Kab. Lampung Utara Tahun 2019 sebanyak 36 siswi. Teknik sampling yang digunakan adalah total sampling.

Hasil: Nilai rata-rata pengetahuan sebelum diberikan penyuluhan kesehatan 9,11 sesudah 14,78 dengan standar deviasi 2,493 dan 2,166 dengan selisih nilai 12,621. Berdasarkan Uji $T$ di dapatkan $p$-value 0,044, bahwa terdapat pengaruh penyuluhan kesehatan terhadap pengetahuan tentang menarche pada siswi kelas $V$

Simpulan: Diharapkan hasil penelitian ini dapat dijadikan salah satu informasi kesehatan bagi tenaga kesehatan agar dapat memberikan penjelasan kepada seluruh masyarakat tentang menarche, sehingga sudut pandang atau stigma tentang menarche tidak buruk. Serta puskesmas rutin melaksanakan promosi kesehatan ke masyarakat melalui meda cetak seperti leaflet, poster dan banner yang berhubungan dengan menarche.

\section{Kata Kunci: Penyuluhan; Kesehatan; Pengetahuan; Menarche; Siswi kelas VI}


Penyuluhan kesehatan tentang menarche menggunakan metode ceramah pada siswi kelas $\mathrm{V} \mathrm{I}$

\section{PENDAHULUAN}

Masa awal remaja merupakan salah satu tahap perkembangan dalam rentang kehidupan manusia. Pada tahap ini remaja akan mengalami suatu perkembangan fisik, seksual dan psikososial sebagai ciri dalam masa pubertas. Remaja ada diantara anak-anak dan orang dewasa.Remaja masih belum mampu menguasai dan memfungsikan secara maksimal fungsi fisik maupun psikisnya (Soetjiningsih, 2007; Harvinta, 2015). Periode perkembangan usia anak sekolah merupakan salah satu tahap perkembangan ketika anak diarahkan menjauh dari kelompok keluarga dan berpusat di dunia hubungan sebaya yang lebih luas. Anak usia sekolah akan mengalami perkembangan dari usia anak menjadi remaja, yang ditandai dengan perubahan fisik pada sebelum masa remajanya (Suryana, 2016).

Masa remaja ditandai dimana seseorang menunjukkan tanda-tanda pubertas dan berlanjut hingga dicapainya kematangan seksual. Pubertas adalah perubahan yang cepat pada kematangan fisik yang meliputi perubahan tubuh dan hormonal ditandai oleh pertumbuhan payudara, pinggul melebar dan membesar, tumbuhnya rambutrambut halus didaerah ketiak dan kemaluan serta dimulainya kematangan seksual yang ditandai dengan menstruasi pertama atau menarche (Proverawati \& Misaroh, 2009). Menarche atau menstruasi pertama remaja putri terjadi pada usia 11 tahun, namun tidak menutup kemungkinan terjadi pada rentang usia 8-16 tahun. Menstruasi merupakan pertanda masa reproduktif pada kehidupan seorang perempuan yang dimulai dari menarche sampai menepouse (Prawirohardjo, 2006; Sibagarian, 2016). Hasil SDKI 2012 menyatakan bahwa $23 \%$ perempuan usia 12 tahun dan 7\% usia10-11 tahun sudah mengalami menarche dan $89 \%$ usia menarche remaja Indonesia termasukdalam rentang usia 12-15 tahun. Persentase inimengalami kenaikan dari hasil (Badan Kependudukan dan Keluarga Berencana Nasional, 2007; Febriansah, Luthfia, Palupi, \& Ikawati, 2016).Kondisi di lapangan menunjukkan bahwa rata-rata remaja putri memperoleh informasi tentang pubertas dari guru $(61 \%)$ dan teman $(29 \%)$. Seperempat remaja tidak pernah membicarakan tentang menstruasi sebelum dirinya mengalami menarche. Hal ini diperburuk dengan pengetahuan masa subur wanita sebesar $16 \%$ dan persepsi persetujuan hubungan seksual pranikah sebesar $7 \%$ dengan alasan saling menyukai (Badan Pusat Statistik, 2013 ; Febriansah, Luthfia, Palupi, \& Ikawati, 2016). Menstruasi pertama merupakan hal yang wajar dialami oleh setiap wanita normal dan tidak perlu digelisahkan. Pada kenyataannya hal tersebut membuat perasaan bingung, gelisah, tidak nyaman selalu menyelimuti perasaan seorang wanita yang mengalami menstruasi pertama atau menarche. Namun hal ini akan semakin parah apabila pengetahuan remaja mengenai menstruasi ini sangat kurang ditambah lagi pendidikan dari orang tua yang kurang dan mereka menganggap bahwa anak akan mengetahui dengan sendirinya (Proverawati, 2009; Lutfia, 2016).

Pengetahuan yang diperoleh remaja tentang mentruasi akan mempengaruhi persepsi remaja tentang mentruasi pertama (menarche). Jika persepsi yang dibentuk remaja tentang menarche positif, maka hal ini akan berpengaruh pada kesiapan remaja dalam menghadapi menarche (Nagar \& Aimol, 2010). Pengetahuan tentang menstruasi yang kurang mengakibatkan remaja akan menganggap datangnya menarche merupakan gejala dari datangnya suatu penyakit, sehingga menimbulkan kepanikan, dan beberapa remaja juga mengganggap bahwa merasa sangat kotor saat menstruasi pertama, sehingga mereka merasa malu, hal tersebut membuat remaja putri tidak siap menghadapi datangnya menarche, dampak dari ketidaksiapan menghadapi menarche adalah mempunyai risiko 4,079 kali berperilaku vulva hygiene tidak baik dibandingkan dengan remaja putri yang siap menghadapi menarche (Parry, 2011). Pengetahuan siswi tentang menstruasi mempunyai dampak positif juga dapat mempengaruhi kesiapan siswi dalam menghadapi menarche. Penelitian yang menyebutkan bahwa terdapat hubungan pengetahuan siswi tentang menstruasi dengan kesiapan dalam menghadapi menarche, dengan memiliki pengetahuan yang baik tentang menstruasi akan berisiko membuat responden lebih siap dalam menghadapi menarche, begitu sebaliknya (Hermawati, 2016). Pemberian informasi yang positif dari berbagai sumber, kemudian diberikan dengan penuh

Eka Trismiyana"*, Italia ${ }^{2}$, Irma Rani Zofitri ${ }^{3}$

'Diploma III Keperawatan Universitas Malahayati Bandar Lampung. *Email:ekatrismiyana@gmail.com

${ }^{2}$ Stikes Mitra Adiguna Palembang Email: italia.effendi@gmail.com

${ }^{3}$ Rumah Sakit Handayani Kotabumi Lampung Utara Email: irmaranizofitri@yahoo.com 
Penyuluhan kesehatan tentang menarche menggunakan metode ceramah pada siswi kelas Vl

kehangatan dan disertai dengan sikap dukungan serta pengertian akan mengurangi rasa kekhawatiran, rasa terbebani ataupun kesedihan akibat datangnya menarche, sehingga bisa membuat anak lebih siap dalam menghadapi menarche (Ulfah, Nugroho, \& Dharmawan, 2016).

Penyuluhan kesehatan sekolah merupakan masalah penting yang perlu mendapatkan perhatian semua pihak.Sekolah merupakan langkah yang strategis dalam upaya meningkatkan kesehatan masyarakat karena sekolah merupakan lembaga yang sengaja didirikan untuk membina dan meningkatkan sumber daya manusia baik fisik, mental, moral maupun intelektual. Penyuluhan kesehatan melalui sekolah paling efektif diantara usaha kesehatan masyarakat yang lain, karena usia 6-18 tahun mempunyai prosentase paling tinggi dibandingkan dengan kelompok umur yang lain (Notoatmodjo, 2012).

Hasil 3 perbandingan di SD yang berada di kotabumi, yaitu SDN 3 Rejosari, SDN 1 Kalicinta dan SDN 02 Rejosari, dengan perbandingan kejadian menarche terbanyak adalah SDN 02 Rejosari yaitu sebanyak 13 anak, SDN 1 Kalicinta 8 anak, dan SDN 3 Rejosari sebanyak 9 anak. Selanjutnya setelah dikaji lebih lanjut, pihak sekolah belum pernah memberikan penyuluhan atau pendidikan kesehatan tentang reproduksi wanita (menarche) di SD masing-masing.

Berdasarkan hasil prasurvey yang dilakukan terhadap 10 siswi kelas 6 SDN 02 Rejosari yang dipilih secara acak, didapat 3 orang diantaranya telah mengalami haid dan bingung saat pertama kali mendapatkan haid, sedangkan 7 diantaranya belum mengalami haid, namun mengatakan takut jika mengalami haid pertama, hal ini dikarenakan mereka merasa kaget keluarnya darah pada alat genetalianya, dan berdasarkan data wawancara lebih lanjut kepada 7 orang yang belum mengalami haid, mereka mengatakan tidak mengetahui cara menangani haid pertama dan tidak mencari tahu bagaimana cara menangani haid pertama.

Dari latar belakang diatas maka peneliti tertarik melakukan penelitian dengan judul "Pengaruh Penyuluhan Kesehatan Terhadap Pengetahuan Tentang menarche Pada Siswi Kelas VI SDN.02 Rejosari Kota Bumi Kab. Lampung Utara Tahun 2019"

\section{METODE PENELITIAN}

Jenis penelitian kuantitatif, menggunakan desain penelitian metode Quasi Eksperimental dengan pendekatan One group Pretes-Postes. Populasi dalam penelitian ini adalah seluruh siswi kelas V SDN.02 Rejosari Kota Bumi Kab. Lampung Utara Tahun 2019 sebanyak 36 siswi. Teknik sampling yang digunakan adalah total sampling. Materi penyuluhan mencakup tentang pengetahuan tentang menarche diberikan selama 120 menit dan evaluasi pengetahuan siswi diberikan pada hari yang sama setelah penyuluhan. Surat keterangan kelaikan etik yang dikeluarkan oleh Komisi etik penelitian kesehatan Universitas Malahayati Bandar Lampung dengan No. 422/EC/KEP-UNMAL/I/2019.

\section{HASIL}

Tabel 1. Karakteristik Responden ( $\mathrm{N}=36$ )

\begin{tabular}{lcc}
\hline Karakteristik & Frekuensi (f) & Persentase (\%) \\
\hline Posisi Anak Dalam Keluarga & & \\
Sulung & 12 & 30 \\
Tengah & 9 & 25 \\
Bungsu & 15 & 45 \\
Pendidikan Ibu Responden & & \\
SD-SMA & 27 & 75 \\
Sarjana & 9 & 25 \\
\hline
\end{tabular}

Eka Trismiyana", ${ }^{1 *}$ Itia $^{2}$, Irma Rani Zofitri ${ }^{3}$

'Diploma 111 Keperawatan Universitas Malahayati Bandar Lampung. *Email:ekatrismiyana@gmail.com

${ }^{2}$ Stikes Mitra Adiguna Palembang Email: italia.effendi@gmail.com

${ }^{3}$ Rumah Sakit Handayani Kotabumi Lampung Utara Email: irmaranizofitri@yahoo.com 
Penyuluhan kesehatan tentang menarche menggunakan metode ceramah pada siswi kelas $\mathrm{VI}$

Berdasarkan tabel.1 Karateristik responden berdasarkan posisi anak dalam keluarga di dominasi pada anak bungsu sebanyak $15(45 \%)$ dan pendidikan ibu responden antara SD-SMA sebanyak 27 (75\%).

Tabel 2. Pengetahuan Tentang Menarche $\mathrm{N}=36$

\begin{tabular}{llllll}
\hline Pengetahuan & N & Min & Max & Mean & SD \\
& & & & & \\
\hline Sebelum & 36 & 4 & 18 & 9,11 & 2,493 \\
Sesudah & 36 & 11 & 19 & 14,78 & 2.166 \\
\hline
\end{tabular}

Berdasarkan tabel 2. diketahui bahwa nilai rata-rata (mean) pengetahuan siswi sebelum diberi penyuluhan kesehatan adalah 9,11 dengan standar deviasi 2,493. Dan sesudah diberi penyuluhan kesehatan adalah 14,78 dengan standar deviasi 2,166.

Tabel 3. Pengaruh Pendidikan Kesehatan Terhadap Pengetahuan Tentang Menarche

\begin{tabular}{lccccc}
\hline Variabel & N & Mean & SD & p-value & $\begin{array}{c}95 \% \text { Cl } \\
\text { Min-max }\end{array}$ \\
\hline Sebelum diberi Penkes & 36 & 9,11 & 2,493 & 0,044 & $4,755-$ \\
Sesudah diberi Penkes & & 14,78 & 2,166 & & 6,578 \\
& & & & & \\
\hline
\end{tabular}

Berdasarkan tabel 3. diketahui bahwa, nilai ratarata pengetahuan sebelum diberikan penyuluhan kesehatan sebesar 9,11dan sesudah diberikan pendidikan kesehatan sebesar 14,78 dengan standar deviasi 2,493 dan 2,166 dengan selisih nilai 12,621. Berdasarkan uji statistik, Uji $T$ di dapatkan $p$-value 0,044 , atau $p$-value $<0,05$ maka dapat disimpulkan bahwa terdapat pengaruh penyuluhan kesehatan terhadap pengetahuan tentang menarche.

\section{PEMBAHASAN}

Pengaruh Penyuluhan Kesehatan Terhadap Pengetahuan Tentang Menarche

Berdasarkan tabel 2. diketahui bahwa, nilai rata-rata pengetahuan sebelum diberikan penyuluhan kesehatan sebesar 9,11 dan sesudah diberikan penyuluhan kesehatan sebesar 14,78 dengan standar deviasi 2,493 dan 2,166 dengan selisih nilai 12,621. Berdasarkan uji statistik, Uji T di dapatkan $p$-value 0,044 , atau $p$-value $<0,05$ maka dapat disimpulkan bahwa terdapat pengaruh penyuluhan kesehatan terhadap pengetahuan tentang menarche pada siswi-amun pada penelitian tersebut juga terdapat hambatanhambatan seperti kurang kondusifnya kelas dikarenakan pada saat dilakukan penelitian bertepatan pada saat anak sudah pulang sekolah sehingga membuat sebagai siswi ada yang tidak fokus untuk memperhatikan materi yang diberikan, serta kurangnya asisten saat memberikan kuesioner sehingga pada saat anak-anak menjawab kurang diawasi sehingga banyak anak yang berkerja sama untuk mengerjakan soalnya maka dari itu hasil nilai rata-rata setelah diberikan pengetahuan tidak terlalu naik meningkat, dan terakhir kurang lamanya waktu pemberian materi sehingga banyak materi yang belum sempat dijelaskan. Menarche atau menstruasi pertama remaja putri terjadi pada usia 11 tahun, namun tidak menutup kemungkinan terjadi pada rentang usia 8-16 tahun. Menstruasi merupakan pertanda masa reproduktif pada kehidupan seorang perempuan yang dimulai dari menarche sampai menepouse (Sibagarian, 2016).

Menstruasi pertama merupakan hal yang wajar dialami oleh setiap wanita normal dan tidak perlu digelisahkan. Pada kenyataannya hal tersebut membuat perasaan bingung, gelisah, tidak nyaman selalu menyelimuti perasaan seorang wanita yang mengalami menstruasi pertama atau menarche. Namun hal ini akan semakin parah apabila pengetahuan remaja mengenai menstruasi ini sangat kurang ditambah lagi pendidikan dari orang tua yang kurang dan mereka menganggap bahwa anak akan mengetahui dengan sendirinya (Proverawati, 2009; Lutfia, 2016).

Eka Trismiyana ${ }^{1 *}$, Italia ${ }^{2}$, Irma Rani Zofitri ${ }^{3}$

'Diploma 111 Keperawatan Universitas Malahayati Bandar Lampung. *Email:ekatrismiyana@gmail.com

${ }^{2}$ Stikes Mitra Adiguna Palembang Email: italia.effendi@gmail.com

${ }^{3}$ Rumah Sakit Handayani Kotabumi Lampung Utara Email: irmaranizofitri@yahoo.com 
Penyuluhan kesehatan tentang menarche menggunakan metode ceramah pada siswi kelas $\mathrm{VI}$

Pengetahuan yang diperoleh remaja tentang mentruasi akan mempengaruhi persepsi remaja tentang mentruasi pertama (menarche). Jika persepsi yang dibentuk remaja tentang menarche positif, maka hal ini akan berpengaruh pada kesiapan remaja dalam menghadapi menarche (Nagar, \& Aimol, 2010). Pengetahuan tentang menstruasi yang kurang mengakibatkan remaja akan menganggap datangnya menarche merupakan gejala dari datangnya suatu penyakit, sehingga menimbulkan kepanikan, dan beberapa remaja juga mengganggap bahwa merasa sangat kotor saat menstruasi pertama, sehingga mereka merasa malu, hal tersebut membuat remaja putri tidak siap menghadapi datangnya menarche.

Dampak dari ketidaksiapan menghadapi menarche adalah mempunyai risiko 4,079 kali berperilaku vulva hygiene tidak baik dibandingkan dengan remaja putri yang siap menghadapi menarche. Pengetahuan siswi tentang menstruasi mempunyai dampak positif juga dapat mempengaruhi kesiapan siswi dalam menghadapi menarche (Sulistioningsih, 2016). Penelitian yang menyebutkan bahwa terdapat hubungan pengetahuan siswi tentang menstruasi dengan kesiapan dalam menghadapi menarche, dengan memiliki pengetahuan yang baik tentang menstruasi akan berisiko membuat responden lebih siap dalam menghadapi menarche, begitu sebaliknya (Rahayu, Aminoto, \& Anis, 2011; Hermawati, 2016). Pemberian informasi yang positif dari berbagai sumber, kemudian diberikan dengan penuh kehangatan dan disertai dengan sikap dukungan serta pengertian akan mengurangi rasa kekhawatiran, rasa terbebani ataupun kesedihan akibat datangnya menarche, sehingga bisa membuat anak lebih siap dalam menghadapi menarche (Kurniawati, 2011). Pendidikan kesehatan sekolah merupakan masalah penting yang perlu mendapatkan perhatian semua pihak. Sekolah merupakan langkah yang strategis dalam upaya meningkatkan kesehatan masyarakat karena sekolah merupakan lembaga yang sengaja didirikan untuk membina dan meningkatkan sumber daya manusia baik fisik, mental, moral maupun intelektual. Pendidikan kesehatan melalui sekolah paling efektif diantara usaha kesehatan masyarakat yang lain, karena usia 6-18 tahun mempunyai prosentase paling tinggi dibandingkan dengan kelompok umur yang lain (Notoatmodjo, 2012). Penelitian Sebelumnya tentang "Pengaruh
Pendidikan Kesehatan Tentang Menarche Terhadap Kecemasan Menghadapi Menarche Pada Siswa Kelas 4-6 di SDN 24 Ujung Gurun Kecamatan Padang Barat" rata-rata sebelum diberikan pendidikan kesehatan tentang menarche yaitu 31,54 dan sesudah diberikan pendidikan kesehatan yaitu 25,80 . Hal ini terjadi pada rata-rata tingkat kecemasan siswi dalam menghadapi menarche sebelum dan sesudah diberikan pendidikan kesehatan. Dari hasil uji statistik terdapat perbedaan yang bermakna antara nilai tingkat kecemasan sebelum dan sesudah diberikan pendidikan kesehatan dengan nilai signifikan 0,000 .Nilai tersebut menunjukkan bahwa terdapat perbedaan antara sebelum dengan sesudah diberikan pendidikan kesehatan tentang menarche (Nofia, 2016).

Kesimpulan hasil peneliti yang peneliti lakukan sebagian besar responden sebelum di berikan penyuluhan mempunyai pengetahuan yang kurang tentang menarche, hal ini dikarenakan kurangnya informasi kesehatan tentang menarche baik dari pendidikan di sekolah maupun di rumah dan belum pernah adanya penyuluhan pendidikan kesehatan tentang reproduksi wanita (menarche) pada sd tersebut, sebelum di berikan penyuluhan juga didapati rata-rata siswi merasa takut jika mengalami haid pertama dikarenakan merasakan kaget karena keluarnya darah pada genentalia dan mereka juga tidak mencoba mencari tahu bagaimna menangani haid pertama. Setelah penelitian memberikan pendidikan kesehatan tentang menarche, maka pengetahuan responden meningkat, hal ini dilihat juga dari respon anak saat diberikan pertanyaan banyak anak yg antusias untuk menjawab dan menjelaskan lagi apa yang sudah peneliti jelaskan tentang menarche walaupun ada sebagian anak-anak yang kurang focus terhadap materi dikarenakan jam pulang sekolah, hal ini juga dibuktikan dengan hasil penelitian yang peneliti lakukan, diketahui pengetahuan sebelum diberikan pendidikan kesehatan adalah 9,11 dan sesudah diberikan pendidikan kesehatan adalah 14,76.Maka dapat disimpulan bahwa terdapat pengaruh tentang menarche pada siswi kelas V di SDN 02 Rejosari.

\section{SIMPULAN}

Berdasarkan tabel 2, diketahui nilai ratarata(mean) pengetahuan siswi kelas $\mathrm{V}$ Sebelum Diberi Penyuluhan Kesehatan adalah 9,11

Eka Trismiyana ${ }^{1 *}$, Italia ${ }^{2}$, Irma Rani Zofitri ${ }^{3}$

'Diploma 111 Keperawatan Universitas Malahayati Bandar Lampung. *Email:ekatrismiyana@gmail.com

${ }^{2}$ Stikes Mitra Adiguna Palembang Email: italia.effendi@gmail.com

${ }^{3}$ Rumah Sakit Handayani Kotabumi Lampung Utara Email: irmaranizofitri@yahoo.com 
Penyuluhan kesehatan tentang menarche menggunakan metode ceramah pada siswi kelas $\mathrm{VI}$

dengan standar deviasi 2,493. nilai rata-rata (mean) pengetahuan siswi sesudah Diberi Penyuluhan Kesehatan adalah 14,78 dengan standar deviasi 2,166., Berdasarkan uji statistik, Uji $T$ di dapatkan $p$-value 0,044 , atau $p$-value $<0,05$ maka dapat disimpulkan bahwa terdapat pengaruh pendidikan kesehatan terhadap pengetahuan tentang menarche pada siswi kelas $\mathrm{V}$ SDN. 02 Rejosari Kota Bumi Kab. Lampung Utara Tahun 2019.

\section{SARAN}

Diharapkan program penyuluhan ini untuk dapat ditindaklanjuti di sekolah dasar lainnya bekerjasama dengan pihak Puskesmas setempat guna peningkatan pengetahuan dibidang kesehatan dan khususnya pengetahuan tentang organ sexual reproduksi, dimana pada usia tersebut para siswi mengalami perubahan awal secara hormonal.

Berbekal pengetahuan yang cukup, para siswi dapat beradaptasi dengan adanya perubahan fisiologi dan psikologi pada dirinya sehingga tetap dapat mengikuti proses belajar di sekolah tanpa hambatan yang berarti.

\section{DAFTAR PUSTAKA}

Badan Kependudukan dan Keluarga Berencana Nasional. (2007). Remaja, H. L. S. P. B. Di Indonesia Menurut Survey Kesehatan Reproduksi Remaja Indonesia (SKRRI) Tahun 2007. Jurnal Kesehatan Reproduksi, 1(3), 136$44 . \quad$ Diakses dari: https://digilib.bkkbn.go.id/index.php?p=show_d etail\&id=36165\&keywords=

Badan Pusat Statistik. (2013). Survei Demografi dan Kesehatan Indonesia (SDKI) 2012. Jakarta: Badan Pusat Statistik, 44, 122. Diakses dari: https://www.bps.go.id/publication/2013/05/01/c1 5e0fccfd3d035e6746a3b4/statistik-indonesia2013.html

Febriansah, R., Luthfia, I., Palupi, D. K., \& Ikawati, M. (2016). Tomat (Solanum lycopersicum L) sebagai agen kemopreventif potensial.
Harvinta, D. D. R. (2015). Hubungan antara stress akademik dengan kecenderungan perilaku merokok pada mahasiswi fakultas kedokteran umum Universitas Muhammadiyah Surakarta (Doctoral dissertation, Universitas Muhammadiyah Surakarta).

Hermawati, H. (2016). Penerapan Model Pembelajaran Agama Islam bagi Anak Berkebutuhan Khusus di Sekolah Dasar Kota Samarinda. SYAMIL, 4(2).

Kurniawati, H. (2011). Eufemisme dan disfemisme dalam spiegel online. Litera, 10(1).

Nagar, S., \& Aimol, K. R. (2010). Knowledge of adolescent girls regarding menstruation in tribal areas of Meghalaya. Studies of Tribes and Tribals, 8(1), 27-30.

Nofia, V. R. (2016). Pengaruh pendidikan kesehatan tentang menarche terhadap kecemasan menghadapi menarche pada siswa kelas 4-6 di SDN 24 ujung gurun kecamatan Padang Barat. Jurnal Kesehatan Medika Saintika, 7(1).

Notoatmodjo, S. (2012). Promosi Kesehatan dan IImuAplikasi. GEN, Jakarta: Rineka Cipta.

Parry, A. (2011). Management and treatment of local anaesthetic toxicity. Journal of perioperative practice, 21(12), 404-409.

Prawirohardjo, S. (2006). IImu kebidanan. Yayasan Bina Pustaka Sarwono.

Proverawati, A., \& Misaroh, S. (2009). Menarche. Yogyakarta: Nuha Medika.

Rahayu, R.T, Aminoto, C., \& Anis, M.M. (2011). Efektivitas Penyuluhan Peer Group dengan Penyuluhan oleh Petugas Kesehatan terhadap Tingkat Pengetahuan tentang Menarche. Jurnal Ilmiah Kesehatan Keperawatan, 7(3). 
Penyuluhan kesehatan tentang menarche menggunakan metode ceramah pada siswi kelas $\mathrm{VI}$

Sibagariang, E. (2016). Kesehatan Reproduksi Wanita Edisi Revisi. Jakarta: CV. Trans Info Medika.

Soetjiningsih, P. (2007). Dr. SpA (K), IBCLC (penyunting) dalam Tumbuh Kembang Remaja dan Permasalahannya. Cet. 2.

Sulistyaningsih, S. (2016). Respon Masyarakat Desa Sitimulyo Terhadap Pengelolaan Tempat Pembuangan Akhir Sampah (Tpa) Piyungan Bantul Yogyakarta. Jurnal Sosiologi Reflektif, 9(2), 49-78.
Suryana, D. (2016). Pendidikan Anak Usia Dini: Stimulasi \& Aspek Perkembangan Anak. Prenada Media.

Ulfah, Z., Nugroho, D., \& Dharmawan, Y. (2016). Hubungan Pengetahuan dan Sikap dengan Praktik Kesehatan Reproduksi Siswa di Smk "X" Kabupaten Kebumen Triwulan I Tahun 2016. Jurnal Kesehatan Masyarakat (eJournal), 4(4), 265-274. 